\title{
The use of low density lipoprotein receptor activity of lymphocytes to determine the prevalence of familial hypercholesterolaemia in a rural South African community
}

\author{
KRISELA STEYN, MICHAEL J WEIGHT, BRUCE R DANDO, \\ KEVIN J CHRISTOPHER, AND JACQUES E ROSSOUW
}

From the Research Institute for Nutritional Diseases of the South African Medical Research Council, PO Bo 70, Tygerberg 7505, Republic of South Africa.

SUMMARY The diagnosis of heterozygous familial hypercholesterolaemia in three rural South African communities in which hypercholesterolaemia is very prevalent could be confirmed by theे measurement of low density lipoprotein (LDL) receptor activity in circulating lymphocytes. nominal cut off point could be proposed which separated the LDL receptor activity of 2 果 clinically diagnosed heterozygous FH patients and 31 healthy people. LDL receptor activity waE measured as total degradation of ${ }^{125} \mathrm{I}-\mathrm{LDL}$ and expressed as $\mathrm{ng} \mathrm{LDL} / \mathrm{mg}$ cell protein/6 hours. The cut off point was set at $970 \mathrm{ng} / \mathrm{mg}$ protein/6 hours. This proposed cut off point was tested by assaying the LDL receptor of three homozygous FH patients and seven of their obligate heterozygous FH first degree relatives. The three homozygous FH patients showed no recepto흔 activity and the activity of the seven obligate heterozygous first degree relatives fell below the proposed cut off point. To determine the prevalence of $\mathrm{FH}$ in the study population, all person $\$$ aged 15 to 24 years whose total cholesterol levels fell above the 80th centile for their age and sex $\overrightarrow{0}$ as well as their families, were approached $(n=114)$. The LDL receptor activity in lymphocytes ô 77 of these persons aged 15 to 24 years was determined after applying the exclusion criteria. Ten of the 77 participants had LDL receptor activity below $970 \mathrm{ng} \mathrm{LDL} / \mathrm{mg}$ protein/6 hours and were. therefore diagnosed as being heterozygous $\mathrm{FH}$ patients. The calculation of the prevalence्ड (corrected for exclusions) revealed that one in 71 of the 15 to 24 year old permanent residents ifi the predominantly Afrikaans speaking community suffered from heterozygous FH. This is highe than any $\mathrm{FH}$ prevalence previously reported for any group.

The high coronary heart disease (CHD) mortality rate in South African whites, and particularly the Afrikaans speaking members of that ethnic group, has in part been ascribed to the high prevalence of familial hypercholesterolaemia $(\mathrm{FH}) .{ }^{1}$ In the Witwatersrand area, where the disease has been reported to have a particularly high prevalence rate in the Afrikaans community, ${ }^{2-4}$ the disease appears to cluster among members of a particular Afrikaans religious denomination. It has been postulated that this finding points towards a genetic isolate. ${ }^{5}$ Seftel $e t a l^{2}$ showed that in this group the homozygote prevalence was approximately 1:30 000. This could

Received for publication 2 January 1988 .

Revised version accepted for publication 19 April 1988. have been an underestimate of the true prevalences as these researchers could not be sure that they ha黑 traced every homozygote in the study area. The finding of a high prevalence of $\mathrm{FH}$ in the southo western Cape area in a predominantly Afrikaans speaking community, ${ }^{6}$ the majority of whom belong to religious groups other than to the one describe in the Witwatersrand, identified the need to deter mine accurately the true prevalence of $\mathrm{FH}$ in the Afrikaans speaking white community of Sout Africa.

The FH prevalence rates described above $\mathrm{e}^{2-6}$ were based on clinical observations and total serun cholesterol level determinations. It remains a probe lem to diagnose heterozygous $\mathrm{FH}$ patients positivel in populations in which polygenic hypercholester 
olaemia is as prevalent as in South Africa. ${ }^{78}$ It was therefore clear that a more accurate estimate of the prevalence of heterozygous $\mathrm{FH}$ would have to be based on a more immediate expression of the pathophysiology of this disease than serum cholesterol.

Studies of cultured skin fibroblasts ${ }^{9} 10$ and freshly isolated human lymphocytes ${ }^{11-13}$ have shown that cells from $\mathrm{FH}$ homozygotes express little or no low density lipoprotein (LDL) receptor activity even when maximally 'upregulated' and therefore show no high affinity degradation of LDL. ${ }^{89}$ Fibroblasts and lymphocytes from $\mathrm{FH}$ heterozygotes usually express half the normal number of LDL receptors when fully 'upregulated' and hence degrade LDL at about half the normal rate. ${ }^{913}$ The deficiency of LDL receptors in liver and perhaps also in peripheral tissues accounts for the greatly increased plasma concentrations of LDL in FH. ${ }^{14}$ Bilheimer $e t$ $a l^{13}$ have successfully used the direct LDL receptor assay in freshly isolated mononuclear cells to discriminate between small numbers of normal healthy subjects, non-FH hyperlipidaemic subjects, and true FH heterozygotes.

In this study we attempted to determine the $\mathrm{FH}$ prevalence in three rural South African communities directly by means of the LDL receptor activity measured in freshly isolated lymphocytes by methodology adapted from that described by Bilheimer $e t$ al. ${ }^{13}$

\section{Subjects and methods}

\section{LDL RECEPTOR CUT OFF POINT \\ DETERMINATION}

A study was undertaken to establish a cut off point for the LDL receptor activity which would best distinguish between the LDL receptor activity in circulating lymphocytes of known heterozygous FH patients and that of normal persons. Twenty-four clinically diagnosed heterozygous $\mathrm{FH}$ patients (11 women and 13 men aged seven to 62 years) were compared with 31 normal persons ( 11 women and 20 men aged 15 to 53 years). To be included as a heterozygous FH patient, the subjects had to have a total serum cholesterol value $\geqq 7 \cdot 0 \mathrm{mmol} / \mathrm{l}$ and also to have at least two of the following: tendon xanthomata, a family history of CHD in at least one first degree relative under the age of 50 years, or a first degree relative with similarly raised plasma cholesterol and tendon xanthomata. Participants were classified as normal when their total cholesterol values were $\leqq 5.7 \mathrm{mmol} / \mathrm{l}$ and no family history of CHD or clinical stigmata of FH were present.

The LDL receptor activity cut off point suggested from the above study was tested by determining the
LDL receptor activity of seven obligate heterozygote $\mathrm{FH}$ patients (five women and two men aged seven to 52 years) and three of their homozygote $\mathrm{FH}$ first degree relatives (three women aged 15 to 33 years). The homozygote $\mathrm{FH}$ were classified as such on the basis of a total cholesterol value of $\geqq 15$ $\mathrm{mmol} / \mathrm{l}$ before treatment and the presence of tendon or cutaneous xanthomata at an early age, as well as an autosomal dominant pattern of inheritance of $\mathrm{FH}$ in their relatives from both parental lines.

The reproducibility of the assay was estimated by studying the lymphocytes from the same subjects on at least three occasions. Two heterozygote participants and two normal participants were studied.

\section{THE FH PREVALENCE STUDY}

To determine the prevalence of $\mathrm{FH}$ in a young, white, predominantly Afrikaans speaking, rural population of three south-western Cape towns, all subjects between the ages of 15 and 24 years resident in this region were approached. The response rate was $72 \%$. Non-fasting total cholesterol (TC) levels were determined on the 976 permanently resident responders. Those whose TC levels were above the 80th centile for their age and sex were identified as the target population. The 114 such subjects and their first degree relatives (at least one parent and one sib per family) were invited to participate in a further investigation which included fasting plasma TC determinations, lipoprotein fractionation, apoprotein $\mathrm{A} 1$ and $\mathrm{B}$ determinations, clinical examinations for stigmata of $\mathrm{FH}$, and the taking of a family history of CHD. These results will be reported separately.

Of these 114 index patients, the LDL receptor activity was determined in 77 participants. The remainder were excluded on one or more of the following grounds: pregnancy, refusal, another sib in the study, insufficient family members available, or index patients who could not be studied (for example, because of military training).

\section{LABORATORY METHODS}

The serum total cholesterol was measured on a Gilford autoanalyser using the Boehringer CHODPAP enzymatic method and calibrated against the Boehringer Mannheim Precilip EL control sera. Two control samples were included in each batch analysed. Human LDL (density $=1.019$ to 1.063 $\mathrm{g} / \mathrm{ml}, 1019$ to $1063 \mathrm{~kg} / \mathrm{m}^{3}$ ) was isolated by differential ultracentrifugation at $10^{\circ} \mathrm{C}$ from plasma donated by normolipidaemic subjects. The LDL was labelled by a modification ${ }^{15}$ of the iodine monochloride method of MacFarlane. ${ }^{16}$

Specific radioactivity levels were in the range of 150 to $350 \mathrm{cpm} / \mathrm{ng}$ of protein and less than $1 \%$ of the 
total radioactivity in the final preparations came from free iodide (quantified as trichloroacetic acid soluble radioactivity). The LDL was used within 10 days of being labelled. Lipoprotein deficient serum (LPDS) was prepared from the plasma of healthy subjects by differential ultracentrifugation at a density of $1.215 \mathrm{~g} / \mathrm{ml}\left(1215 \mathrm{~kg} / \mathrm{m}^{3}\right) .{ }^{17}$

Lymphocytes were isolated from $50 \mathrm{ml}$ blood drawn from the subjects and defibrinated in sterile glass tubes. After centrifugation at $800 \mathrm{~g}$ for 30 minutes, mononuclear cells were isolated by first diluting the buffy coat in one volume of RPMI 1640 tissue culture medium (Flow Laboratories, Irving, Scotland) and then the resultant cell suspension 1:1 with more RPMI 1640. Of the diluted cells, $6 \mathrm{ml}$ were then layered onto $3 \mathrm{ml}$ Ficoll-Hypaque of density $1.077 \mathrm{~g} / \mathrm{ml}\left(1077 \mathrm{~kg} / \mathrm{m}^{3}\right)^{18}$ and centrifuged for 40 minutes at $400 \mathrm{~g}$. The interface of mononuclear cells was harvested and washed three times by recentrifugation through Eagle's medium. Of the mononuclear cells prepared in this manner, more than $95 \%$ were lymphocytes, confirmed by the trypan blue exclusion tests.

The maximum LDL receptor activity was quantified by the proteolytic degradation of ${ }^{125}$ I-LDL by blood mononuclear cells after prior incubation in the absence of lipoproteins to 'upregulate' the LDL receptor number, using a method similar to that of Bilheimer et al. ${ }^{13}$ LDL catabolism was quantified from the accumulation of trichloroacetic acid soluble non-iodide radioactivity in the medium. Cellular degradation of ${ }^{125} \mathrm{I}-\mathrm{LDL}$ was calculated as the difference between results obtained from identical incubations with and without cells, and the results expressed as ng ${ }^{125} \mathrm{I}-\mathrm{LDL} / \mathrm{mg}$ cell protein/ 6 hours. Mistry et al ${ }^{19}$ have shown that, at the concentration of ${ }^{125} \mathrm{I}-\mathrm{LDL}$ used $(10 \mu \mathrm{g}$ protein $/ \mathrm{ml})$, approximately $90 \%$ of the cellular degradation occurs via the receptors with high affinity for LDL. Measurements were performed in triplicate and normal and heterozygote subjects were assayed on the same day.

CALCULATION OF PREVALENCE

Subjects with an LDL receptor activity below the selected cut off point ( $970 \mathrm{ng} \mathrm{LDL} / \mathrm{mg}$ cell protein/ 6 hours) were labelled as FH heterozygotes. The prevalence of $\mathrm{FH}$ in this community was estimated and was corrected for the exclusions mentioned above.

\section{Results}

The LDL receptor activity in freshly isolated mononuclear cells of clinically diagnosed heterozygous FH patients and normal participants are shown in the figure (a). These results showed that the receptor activity expressed as total degradation of ${ }^{125}$ I-LDL in lymphocytes can discriminate between FH heterozygotes and healthy subjects. A cut off point of $970 \mathrm{ng}$ LDL catabolised per mg cell proteif in six hours allowed optimal separation of F/ heterozygote and normal subjects.

Repeat measurements on the two known hetero zygote patients and the two normal participants haep a mean coefficient of variance (CV) of $12 \%$ fọ heterozygote participants and $14.5 \%$ for the normat participants. This is of the same magnitude as the $\mathrm{CV}$ reported by Bilheimer et al. ${ }^{13}$

The testing of the cut off point against the LDढ़ receptor assay results of obligate heterozygotes anfos homozygote $\mathrm{FH}$ patients is shown in the figure (b). The homozygote FH patients showed no LDF receptor activity and none of the heterozygous FH patients had LDL receptor activities above the suggested cut off point. The heterozygous patients were found to have an $L D L$ receptor activit between 429 and $960 \mathrm{ng}$ LDL catabolised per mg cem protein in six hours. The range of the receptor activity of normal participants was between 999 anळ

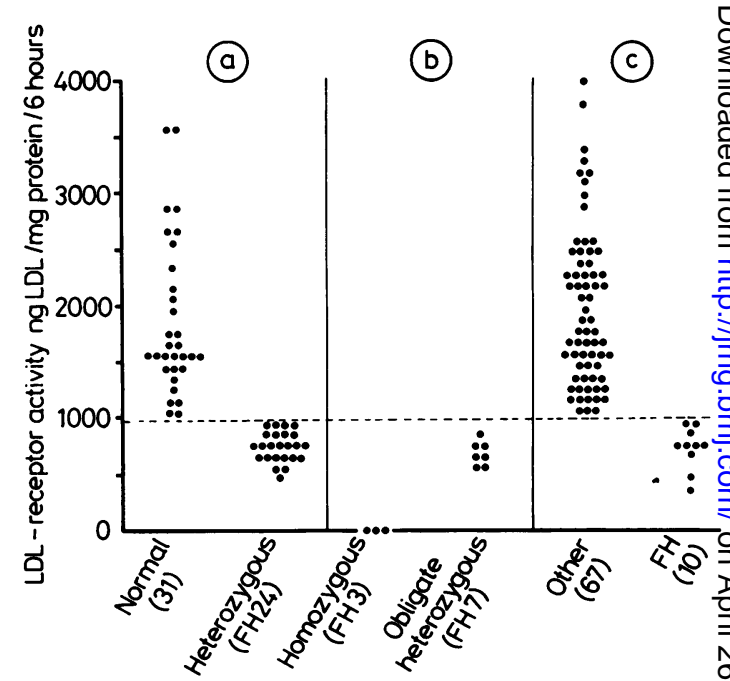

FIGURE Low density lipoprotein receptor activity expressed as ng LDL/mg cell protein/6 hours was determined in lymphocytes of (a) 24 clinically identified heterozygous familial hypercholesterolaemic $(F H)$ patients and compared to those of 31 normal subjects, with the rang? of values of the two groups suggesting a nominal cut off point of $970 \mathrm{ng}$ LDL/mg cell protein/6 hours; (b) three homozygous FH patients and seven of their obligate heterozygous FH first degree relatives, lending support to the proposed cut off point; (c) a group of 77 hypercholesterolaemic participants in which 10 heterozygous FH patients could be identified on the basis of the proposed cut off point. 
$3530 \mathrm{ng}$ LDL catabolised per mg cell protein in six hours.

The cut off point of $970 \mathrm{ng}$ LDL degraded per $\mathrm{mg}$ cell protein per six hours identified 10 of the 77 index patients aged 15 to 24 years with LDL receptor activity corresponding to that of heterozygous FH patients. These results are shown in the figure (c).

The prevalence of heterozygous $\mathrm{FH}$ in the 15 to 24 year old permanent residents in the predominantly Afrikaans speaking rural population of three southwestern Cape towns was calculated, and this calculation included a correction for the exclusions. Table 1 shows the prevalence of $\mathrm{FH}$ to be one in 71 in the study population.

The usual diagnostic features of heterozygous $\mathrm{FH}$ in the group identified as such is compared with those participants with normal LDL receptor activity in table 2. The heterozygous FH group had significantly higher total and LDL cholesterol values and significantly more first degree relatives with a history of CHD and tendon xanthomata. Of importance is the fact that many of the first degree relatives of the non-FH index patients also suffered from CHD and were found to have tendon xanthomata.

TABLE 1 The figures used in the calculation of the prevalence of familial hypercholesterolaemia in the rural predominantly Afrikaans speaking white population of three western Cape towns.

\begin{tabular}{lr}
\hline Permanent residents aged 15 to 24 years & 976 \\
Residents with total cholesterol levels $\geqq 80$ th centile & 114 \\
Residents excluded on various criteria & 37 \\
Participants with LDL receptor assays & 77 \\
Participants with LDL receptor levels below the cut off point & 10 \\
of $970 \mathrm{ng} / \mathrm{mg}$ protein/6 hours=heterozygous FH patients & 12.99 \\
$\%$ heterozygous participants & 1.02 \\
FH prevalence not corrected (\%) & 1.41 \\
FH prevalence corrected for exclusions (\%) & $1: 71$ \\
\hline
\end{tabular}

\section{Discussion}

Although an arbitrary discrete cut off point of 970 ng LDL catabolised per mg cell protein in six hours was chosen to distinguish between $\mathrm{FH}$ and non-FH hypercholesterolaemic index cases, it is clear from the coefficients of variation that misclassification can occur which will affect the calculated prevalence of heterozygous $\mathrm{FH}$ in the study population. The clinical finding of tendon xanthomata in the first degree relatives of non-FH index patients may point to such a misclassification. While fully acknowledging this limitation of the choice of a discrete cut off point, we felt justified in using it after verifying it against LDL receptor activities of obligate heterozygous patients, and in view of the suspected magnitude of this undiagnosed disease in the study population the need for a defined diagnostic criterion, even with limitations, became necessary.

The estimated prevalence of $\mathrm{FH}$ of 1:71 in the Afrikaans speaking South African study community is er $2 n$ higher than the 1:100 reported by Seftel et al using the Hardy-Weinberg equation ${ }^{20}$ in the Afrikaans group of a specific religious denomination ${ }^{5}$ in the Witwatersrand. Jooste et al ${ }^{6}$ estimated the prevalence to be at least $1: 87$, based on TC values, in the same communities as the present study. The FH prevalence rate based on the LDL receptor assay is the highest ever reported and supports the suggestion made by Seftel et $a l^{2}$ and Pretorius ${ }^{1}$ that FH has made a significant contribution to the extremely high CHD mortality among South African whites. To our knowledge this is the first study which has used the LDL receptor assay to estimate directly the $\mathrm{FH}$ prevalence in a population.

A plausible explanation for the high $\mathrm{FH}$ prevalence in South African whites compared to other populations ${ }^{21}$ could be the founder gene effect suggested by Seftel $e t a l^{2}$ and Torrington et al. ${ }^{5} \mathrm{~A}$

TABLE 2 Comparison of diagnostic features of familial hypercholesterolaemia in the two groups of index patients aged 15 to 24 years.

\begin{tabular}{lll}
\hline & $\begin{array}{l}\text { Participants } \\
\text { with LDL } \\
\text { receptor activity } \\
\text { suggestive of FH }\end{array}$ & $\begin{array}{l}\text { Participants } \\
\text { with } \\
\text { LDLrmal } \\
\text { activity } \\
\text { receptor }\end{array}$ \\
\hline $\begin{array}{l}\text { Number of participants } \\
\text { Total serum cholesterol in } \\
\text { mmoll (SD) }\end{array}$ & 10 & 67 \\
$\begin{array}{l}\text { Low density lipoprotein } \\
\text { cholesterol in mmol/ (SD) }\end{array}$ & $7 \cdot 13$ & $6 \cdot 10$ \\
$\begin{array}{l}\text { History of coronary heart } \\
\text { disease in first degree } \\
\text { relatives of index patients }\end{array}$ & $(1 \cdot 20)$ & $\mathbf{0 \cdot 8 3 )}$ \\
$\begin{array}{l}\text { Tendon xanthomata in } \\
\text { index patients }\end{array}$ & $5 \cdot 30$ & $(0 \cdot 85)$ \\
$\begin{array}{l}\text { Tendon xanthomata in first } \\
\text { degree relatives of index } \\
\text { patients }\end{array}$ & $65 \%$ & $29 \%$ \\
\hline
\end{tabular}


study by Van der Westhuyzen $e^{2} a^{22}$ indicated that the LDL receptor abnormality found in South African homozygous FH patients was predominantly of the receptor defective type. This finding supports the founder gene effect hypothesis, since Tolleshaug et a ${ }^{23}$ have described at least seven mutations that could affect the LDL receptor phenotype where the receptor defective type did not predominate, as found in the reported ${ }^{22}$ South African study.

The results of the present study found the high prevalence of $\mathrm{FH}$ in a white Afrikaans speaking community which does not belong to the specific church affiliation described by Torrington et al. ${ }^{5}$ Therefore, if the founder gene effect is to be validated, it would probably have to be illustrated in forebears who were not exclusively members of the South African Gereformeerde Church.

A recent study by Kotze et $a l^{4}$ identified three DNA polymorphisms at the human LDL receptor gene locus of South African families clinically diagnosed as suffering from FH. Although one of the DNA polymorphisms was found more often than the other two, the presence of the latter two DNA polymorphisms provides evidence against a single mutation causing the founder gene effect. These findings, as well as the variation in receptor activity in the receptor defective FH homozygotes described by Van der Westhuyzen et al, ${ }^{22}$ and the variation in clinical manifestation of the disease in affected families, weighs against a single founder gene effect as the only explanation for the high prevalence of $\mathrm{FH}$ in white Afrikaans speaking South Africans.

It is likely that our estimated 1:71 prevalence of FH is representative of Afrikaans speaking whites, since it agrees with previous estimates in other parts of South Africa. ${ }^{2}$ The methodology used is based on direct measurement of the cellular abnormality found in FH. The possibility for misclassification is present, but unlikely to be of a magnitude that will negate the finding of a high prevalence of $\mathrm{FH}$ in the study population. Until gene markers suitable for population screening programmes are found, the present method is a useful alternative.

\section{References}

${ }^{1}$ Pretorius JPG. High ischaemic heart disease mortality among young Afrikaners. S Afr Med J 1983;64:427-9.

2 Seftel HC, Baker SG, Sandler MP, et al. A host of hypercholesterolaemic homozygotes in South Africa. $\mathrm{Br}$ Med $J$ 1980;281:633-6.

3 Jenkins T, Nicholls E, Gordon E, Mendelsohn D, Seftel HC, Andrew MJA. Familial hypercholesterolaemia-a common genetic disorder in the Afrikaans population. $S$ Afr Med J 1980;57:943-7.

${ }^{4}$ Stein EA. The Lipid Disorders Centre at the Transvaal Memorial Hospital for Children: a review of the first 30 months. $S$ Afr Med J 1977;52:573-9.
5 Torrington M, Botha JL, Pilcher GJ, Baker SG. Association: between familial hypercholesterolaemia and church affiliation. Afr Med J 1984;65:762-7.

6 Jooste PL, Benadé AJS, Rossouw JE. Prevalence of familią hypercholesterolaemia in three rural South African communio ties. $S$ Afr Med J 1986;69:548-51.

${ }^{7}$ Rossouw JE, Du Plessis JP, Benadé AJS, et al. Coronary ris factor screening in three rural communities: the CORIS baselin 2 study. S Afr Med J 1983;64:430-6.

${ }^{8}$ Steyn K, Benadé AJS, Langenhoven ML, et al. Hypercholesterolaemia in the coloured population of the Cape Peninsul (Crisic study). S Afr Med J 1987;71:483-6.

9 Goldstein JL, Brown MS. The low density lipoprotein pathwa $\vec{\omega}$ and its relation to atherosclerosis. Annu Rev Biochem 1977;469 897-930.

16 Goldstein JL, Brown MS. Binding and degradation of low density lipoproteins by cultured human fibroblasts: comparisoñ of cells from a normal subject and from a patient with homozygous familial hypercholesterolaemia. J Biol Chem $1974 \overrightarrow{\mathrm{\omega}}$ 249:5153-62.

1 Ho YK, Brown MS, Bilheimer DW, Goldstein JL. Regulatio@ of low density lipoprotein receptor activity in freshly isolated human lymphocytes. J Clin Invest 1976;58:1465-74.

12 Ho YK, Faust JR, Bilheimer DW, Brown MS, Goldstein JL ֻ Regulation of cholesterol synthesis by low density lipoprotein ip isolated human lymphocytes. J Exp Med 1977;145:1531-49. ำ

13 Bilheimer DW, Ho YK, Brown MS, Anderson RGW, Goldstein JL. Genetics of the low density lipoprotein receptor: diminished receptor activity in lymphocytes from heterozygotes with famio lial hypercholesterolaemia. J Clin Invest 1978;61:678-96.

14 Myant NB. The metabolic basis of familial hypercholestero laemia. Klin Wochenschr 1983;61:383-401.

15 Langer T, Strober W, Levy RI. The metabolism of low densit lipoprotein in familial hypercholesterolaemia. J Clin Inves 1972;51:1528-36.

${ }^{16}$ MacFarlane AS. Efficient trace labelling of proteins with iodine Nature 1958;182:53.

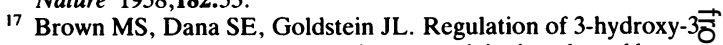
methylglutaryl coenzyme A reductase activity in cultured huma $\bar{\Phi}$ fibroblasts. J Biol Chem 1974;249:789-96.

18 Boyum A. Isolation of mononuclear cells and granulocytes from human blood. Scand J Clin Lab Invest (Suppl) 1967;97:77-89.

${ }_{19}$ Mistry P, Miller NE, Laker WA, Hazzard WR, Lewis B Individual variation in the effects of dietary cholesterol o plasma lipoproteins and cellular cholesterol homeostasis in man'studies of low density lipoprotein receptor activity and 3 hydroxy-3-methylglutaryl coenzyme A reductase activity blood mononuclear cells. J Clin Invest 1981;67:493-502.

20 Emery AEH. Methodology in medical genetics. Edinburgh Churchill Livingstone, 1976.

${ }^{21}$ Motulsky AG. The genetic hyperlipidemias. N Engl $J$ Me 1976;26:823-7.

22 Van der Westhuyzen DR, Coetzee GA, Demasius IPC, et aE. Low density lipoprotein receptor mutations in South Africa homozygous familial hypercholesterolemic patients. Arteriơ sclerosis 1984;4:238-47.

23 Tolleshaug H, Hobgood KK, Brown MS, Goldstein JL. The LDL receptor locus in familial hypercholesterolemia: multiples mutations disrupt transport and processing of a membrane receptor. Cell 1983;32:941-51.

24 Kotze MJ, Langenhoven E, Retief AE, et al. Haplotype associations of three DNA polymorphisms at the human lo density lipoprotein receptor gene locus in familial hype cholesterolaemia. J Med Genet 1987;24:750-5.

Correspondence and requests for reprints to Dr Steyn, Centre for Epidemiological Research iक Southern Africa, Box 70, Tygerberg 7505, Soutf Africa. 